\title{
Evaluation of Different Weed Management Strategies in Clusterbean [Cyamopsis tetragonoloba (L.) Taub] under Rainfed Conditions of Punjab
}

\author{
Rupinder Singh, Balwinder Singh Dhillon
}

10.18805/LR-4770

\begin{abstract}
Background: Generally, farmers cultivate clusterbean [Cyamopsis tetragonoloba (L.) Taub] on rainfed area but seldom adopt weed control practices in it. It becomes very difficult and uneconomical to maintain weed free environment throughout crop period in the field under rainfed conditions. Therefore, the current study was aimed to find an effective weed control practice in clusterbean under rainfed conditions.

Methods: Effect of weed management practices of clusterbean with $T_{1}$ : Pendimethalin @ 1 litre/ha (PE), $T_{2}:$ Imazethapyr @ $0.1 \mathrm{~kg} /$ ha at 20 days $(\mathrm{POE}), \mathrm{T}_{3}$ : Stale bed technology, $\mathrm{T}_{4}$ : One hand weeding at $20 \mathrm{DAS}$ (days after sowing), $\mathrm{T}_{5}$ : Two hand weedings at 20 and 40 DAS, $T_{6}$ : Imazethapyr @ $0.1 \mathrm{~kg} / \mathrm{ha}$ at 20 days + hand weeding at $40 \mathrm{DAS}, \mathrm{T}_{7}$ : Pendimethalin @ 1 litre/ha (PE) + hand weeding 35 DAS, $T_{8}$ : Pendimethalin @ 1 litre /ha $(P E)+$ imazethapyr $0.1 \mathrm{~kg} / \mathrm{ha}$ at $30 \mathrm{DAS}$ and $\mathrm{T}_{9}$ : Weedy check were investigated under rainfed conditions.

Result: Weed control efficiencies of imazethapyr @ $0.1 \mathrm{~kg} / \mathrm{ha}$ at 20 days + hand weeding at $40 \mathrm{DAS}\left(\mathrm{T}_{6}\right)$, pendimethalin @ 1 litre/ha + hand weeding at 40 DAS $\left(T_{7}\right)$ and pendimethalin @ 1 litre/ha $(P E)+$ imazethapyr @ $0.1 \mathrm{~kg} / \mathrm{ha}$ at 20 days $(\mathrm{PoE})\left(\mathrm{T}_{8}\right)$ were statistically similar. Imazethapyr @ $0.1 \mathrm{~kg} / \mathrm{ha}$ at 20 days (PoE) + one hand weedings at 40 DAS recorded higher growth characters viz., plant height, dry matter and yield attributing characters viz., number of branches, number of pods/plant and seed index than other treatments. The highest seed yield was recorded in imazethapyr @ $0.1 \mathrm{~kg} / \mathrm{ha}$ at 20 days (PoE) + one hand weedings at 40 DAS (422 kg/ha), being statistically at par with pendimethalin @ 1 litre/ha (PE) + one hand weedings at $40 \mathrm{DAS}(390 \mathrm{~kg} / \mathrm{ha})$ and pendimethalin @ 1 litre/ha (PE) + imazethapyr @ $0.1 \mathrm{~kg} / \mathrm{ha}$ at 20 days (PoE) $(392 \mathrm{~kg} / \mathrm{ha})$ which was significantly higher than other treatments. Imazethapyr @ $0.1 \mathrm{~kg} / \mathrm{ha}$ at 20 days (PoE) + one hand weedings at 40 DAS recorded 27.9 and 33.9 per cent higher seed yield than imazethapyr @ $0.1 \mathrm{~kg} / \mathrm{ha}$ at 20 days (PoE) and one hand weedings at $40 \mathrm{DAS}$, respectively. The net returns and benefitcost ratio were maximum for imazethapyr @ $0.1 \mathrm{~kg} / \mathrm{ha}$ at 20 days $(\mathrm{PoE})+$ hand weeding at $40 \mathrm{DAS}\left(\mathrm{T}_{6}\right)$. It is inferred that imazethapyr @ $0.1 \mathrm{~kg} / \mathrm{ha}$ at 20 days $(\mathrm{PoE})+$ one hand weedings at 40 DAS was found the most effective and economic approach for weed control in clusterbean under rainfed conditions.
\end{abstract}

Key words: Clusterbean, Net returns, Seed yield, Stale bed technology, Weed management.

\section{INTRODUCTION}

Clusterbean [Cyamopsis tetragonaloba (L.) Taub], a kharif pulse crop is considered as one of the most drought tolerant deep-rooted and annual legume in India (Meena et al., 2016). The crop is grown for fresh vegetable and for gum purpose. The crop survives best even at moderate levels of salinity and alkalinity. In India, the crop is mainly grown in the dry habitats of Rajasthan, Haryana, Gujarat and Punjab and to a limited extent in Uttar Pradesh and Madhya Pradesh. In India, the total area under clusterbean was 42.55 lakh ha with a production of 24.15 lakh tons green pod and a productivity of $567.0 \mathrm{~kg}$ ha during 2019-20. In Punjab, cluster bean was cultivated on area 48,600 ha with production of 33,400 tons and average productivity was $688.0 \mathrm{~kg} \mathrm{ha}^{-1}$ during 2019-20 (Anonymous, 2021). The use of clusterbean gum has increased tremendously viz., natural absorbent, in textile, printing, cosmetics, mining, explosive, oil industry, petroleum, pharmaceuticals, food processing etc.

Weed is one of the most important factors responsible for lower yield of crop (Islam et al., 1989). Weed-crop
Department of Agronomy, Guru Kashi University, Talwandi Sabo151 302, Punjab, India.

Corresponding Author: Balwinder Singh Dhillon, Regional Research Station, Punjab Agricultural University, Ballowal Saunkhri, SBS Nagar-144 521, Punjab, India.

Email: dhillonbalwinder@pau.edu

How to cite this article: Singh, R. and Dhillon, B.S. (2022). Evaluation of Different Weed Management Strategies in Clusterbean [Cyamopsis tetragonoloba (L.) Taub] under Rainfed Conditions of Punjab. Legume Research. DOI: 10.18805/LR-4770.

Submitted: 16-08-2021 Accepted: 20-12-2021 Online: 24-01-2022 competition commences with germination of the crop and continues till its maturity. Several growth stages of clusterbean such as emergence, flowering and fruiting stages are greatly hampered from weed competition. Weed infestation of these stages causes poor crop growth and ultimately it reduces the yield. All crops have a vulnerable stage during their life cycle when they are particularly 
sensitive to weed competition. In general, it ranges up to first 25-50 per cent of the lifetime of crops. The presence of weeds at critical period for weed control (CPWC) leads to serious yield losses (Knezevic et al., 2002). Lack of proper weeding reduced the yield of clusterbean up to 65 per cent (Grichar et al., 2001). The yield of clusterbean can be increased by 21 to 53 per cent with adoption of improved technologies such as improved variety, recommended dose off ertilizer, weed management and plant protection.

Planting clusterbean seeds is difficult because the seeds are small and need to be placed precisely in the soil. Mechanization of clusterbean cultivation therefore requires good weed control for 50 to 60 days after planting (Langham et al., 2007). Weeds at above critical population thresholds can significantly reduce crop yield and quality. However, the aim of weed management should be to maintain weed population at a manageable level with minimum cost. Timely control of weeds either manually or using herbicide is essential for higher harvest yield in clusterbean. Effective herbicides at appropriate rate may prove as a potent weed control method (Verma and Kushwaha, 2020).

The traditional method of weed control is expensive but use of herbicide is convenient and economic. To ensure timely weeding and effective weed control use of herbicide proved its efficacy in many research (Gupta et al., 2014; Verma and Kushwaha, 2020). Still hand weeding is preferable where labour availability is not a problem. Farmers cultivate clusterbean on rainfed area but seldom adopt weed control practices in it. It becomes very difficult and uneconomical to maintain weed free environment throughout crop period in the field under rainfed conditions. Keeping the field weed free with 2-3 hand weedings is laborious, time consuming and costlier weed management approach. In clusterbean, which is a rainfed crop and application of pendimethalin or imazethapyr alone is not found effective to control weeds under such conditions. Therefore, a field experiment was done during kharif seasons (year: 2019 and 2020) to elucidate the efficacy of herbicides i.e., imazethapyr and pendimethalin alone and in combination, along with manual weeding, and stale bed technology under rainfed conditions of Punjab on clusterbean crop.

\section{MATERIALS AND METHODS}

The present investigation was carried out at Research Farm of Guru Kashi University, Talwandi Sabo (Bathinda) during kharif season of 2019 and 2020. Talwandi sabo (Bathinda) is situated at $29^{\circ} 33^{\prime} \mathrm{N}$ latitude and $74^{\circ} 38^{\prime} \mathrm{E}$ longitude at a height of 208 metres above the mean sea level. The experimental site belongs to semi-arid climate, where both summers and winters are acute. A maximum temperature of about $45^{\circ} \mathrm{C}$ is common during summer, while freezing temperature accompanied by frost in the months of December and January. The soil of the experimental field was loamy sand in texture which has $\mathrm{pH} 7.8$ with normal electrical conductivity of $0.22 \mathrm{dSm}^{-1}$. The soil was medium in organic carbon content $(0.30 \%)$. The available nitrogen $\left(215.1 \mathrm{~kg} \mathrm{ha}^{-1}\right)$ was low, whereas the available phosphorus (16.3 kg ha-1) and available potassium (229.5 kg ha-1) were both medium. The experiment included nine treatments viz., $\mathrm{T}_{1}$ : Pendimethalin @ 1 litre/ha (PE), $\mathrm{T}_{2}$ : Imazethapyr @ 0.1 $\mathrm{kg} / \mathrm{ha}$ at 20 days (POE), $\mathrm{T}_{3}$ : Stale bed technology, $\mathrm{T}_{4}$ : One hand weeding at 20 DAS (days after sowing), $\mathrm{T}_{5}$ : Two hand weedings at 20 and 40 DAS, T. Imazethapyr @ $0.1 \mathrm{~kg} / \mathrm{ha}$ at 20 days + hand weeding at 40 DAS, T7: Pendimethalin @ 1 litre/ha $(\mathrm{PE})+$ hand weeding $35 \mathrm{DAS}, \mathrm{T}_{8}$ : Pendimethalin @ 1 litre /ha (PE) + imazethapyr $0.1 \mathrm{Kg} / \mathrm{ha}$ at $30 \mathrm{DAS} \mathrm{T}_{9}$ : Weedy check, replicated thrice. The clusterbean bean variety 'HG 365' was sown on 12 May, 2019 and 5 May, 2020 at a row spacing of $45 \mathrm{~cm}$ using $25 \mathrm{~kg} \mathrm{seed} / \mathrm{ha}$, during first and second year, respectively. A uniform basal dose of nitrogen (30 kg N ha-1) and phosphorous (47 kg $\mathrm{P}_{2} \mathrm{O}_{5} \mathrm{ha}^{-1}$ ) were applied at the time of sowing in the form of urea (46 per cent $\mathrm{N}$ ) and single super phosphate (16 per cent $\mathrm{P}_{2} \mathrm{O}_{5}$ ), respectively. One irrigation was given at pod formation stage of clusterbean. Plant to plant spacing however was maintained by thinning at 15 days after sowing. Herbicidal spray was done either as pre-emergence or post emergence at 20 DAS as per treatment.

Weed density was recorded at 30 and 60 DAS with the help of quadrate $(1 \mathrm{~m} \times 1 \mathrm{~m})$ from each plot. Three quadrate were thrown randomly in each plot and then an average value was worked out. Data on weed density was subjected to square-root transformation $(\sqrt{ } X+1)$ before statistical analysis to normalize their distribution. The relative density of individual weed was worked out as per formula proposed by Mishra (1968).

Relative density (\%) =

Number of individual of the same spieces

Number of individual of the all spieces

Dry weight of weeds in treated plots was recorded at 30 and 60 DAS. For recording dry matter accumulation by weeds, weed plants were removed from ground level by using quadrate of $50 \mathrm{~cm} \times 50 \mathrm{~cm}$, these samples were first sun dried and then dried in oven to attain a constant weight. After drying dry matter accumulation was recorded and expressed as $\mathrm{g} / \mathrm{m}^{2}$.

Weed control efficiency (WCE) was calculated at 30 and 60 DAS with the help of formula given below (Mani et al., 1973):

WCE $(\%)=$

Dry weight of weeds in unweeded control -

$\frac{\text { Dry weight of weeds in treated plot }}{\text { Dry weight of weeds in unweeded control }} \times 100$

Five crop plants were randomly selected from each plot, tagged permanently, and used for measurement of plant height. Dry matter accumulation of crop was recorded at maturity by removing plants from one metre row length from the outer two sample rows in each plot. The branches of five randomly selected and tagged plants from each plot 
were counted at 60 DAS and at maturity. The pods of five randomly selected plants were counted and average number of pods per plant was worked out. Number of seed per pod was recorded at harvest by counting the number of seeds of ten randomly selected pods from five tagged plants and average was taken. A composite sample of seed from each net plot was drawn from the shelled pods and the 100 seeds were weighed separately for each net plot by electronic balance. The weight of total produce/plot was recorded after harvest of the crop with help of spring balance. Then the weight of seeds per net plot was recorded after threshing of the harvested produce from each bundle and means were converted into the seed yield per unit area $(\mathrm{kg} / \mathrm{ha})$. The stover yield was obtained after deducting the seed yield from the total produce of each plot and expressed as $\mathrm{kg} / \mathrm{ha}$. The economics of clusterbean was calculated based on prevailing market price. To calculate the net returns for each treatment, total cost of cultivation was subtracted from the gross returns. Benefit-cost ratio was calculated by dividing gross returns with cost of cultivation.

The experiment was performed during the period of two years. Analysis of variance was performed using Proc GLM procedure of SAS version 9.4 (SAS. 2017) and significant mean differences were tested using Fisher's protected least significant difference (LSD) test at $\alpha=0.05$.

\section{RESULTS AND DISCUSSION}

\section{Effect on weeds}

\section{Weed flora}

The data regarding weed flora (Table 1 ) revealed that the weedy check plots of clusterbean were heavily invaded by annual dicot weeds viz., Amaranthus viridis, Trianthema portulacastrum, Digera arvensis and Phyllanthus niruri immediately with the crop emergence. Euphorbia hirta, Celosia argentia and Commelina benghalensis were the another dicot weeds of minor importance found to infest the experimental field. Cyperus rotundus, Digitaria sanguinalis, Dactyloactenium aegyptium, Cenchrus biflorus and Cynodon dactylon appeared to be the prominent monocot weed species, though, the population of these weeds was low.

\section{Relative weed density}

In the experimental field, Amaranthus viridis, Trianthema portulacastrum, Digera arvensis and Phyllanthus niruri were the most dominant weeds contributing to about 69.02 per cent of the total weed flora at 30 DAS (Table 1). Relative density of monocotyledonous weed viz., Dactyloctenium aegyptium was 8.89 per cent. Whereas, dicotyledonous weed e.g. Amaranthus viridis recorded the highest relative density of $24.98 \%$ at 30 DAS.

\section{Weed density}

The highest weed density $\left(39.3 / \mathrm{m}^{2}\right)$ was recorded in pendimethalin @ 1litre/ha + hand weeding at $40 \mathrm{DAS}\left(\mathrm{T}_{7}\right)$ plots which was significantly higher than other weed control treatments followed by imazethapyr @ $0.1 \mathrm{~kg} / \mathrm{ha}$ at 20 days $\left(T_{2}\right)$ at 30 DAS (Table 2). Stale bed technology $\left(T_{3}\right)$ recorded the lowest weed density $\left(8.0 / \mathrm{m}^{2}\right)$ However at 60 DAS, pendimethalin @ 1 litre/ha $\left(T_{1}\right)$ recorded the highest weed density $\left(40.9 / \mathrm{m}^{2}\right)$, being at par with one hand weeding at 20 DAS $\left(\mathrm{T}_{4}\right)$ and was significantly higher than other weed control treatments. Imazethapyr @ $0.1 \mathrm{Kg} / \mathrm{ha}$ at 20 days + hand weeding at 40 DAS $\left(\mathrm{T}_{6}\right)$ recorded lowest weed density (4.0/ $\mathrm{m}^{2}$ ) followed by two hand weedings at 20 and 40 DAS $\left(T_{5}\right)$. Poor performance of pendimethalin in controlling weeds was due to lack of upper layer moisture of the soil thus reduced

Table 1: Weed population and relative weed density of different associated weed flora in clusterbean crop at 30 DAS (pooled data of 2 year).

\begin{tabular}{lccc}
\hline Botanical name & Family & $\begin{array}{c}\text { Weed population } \\
\left(\text { per } \mathrm{m}^{2}\right)\end{array}$ & $\begin{array}{c}\text { Relative weed } \\
\text { density }(\%)\end{array}$ \\
\hline A. Monocot weeds & Cyperaceae & 3.9 & 3.30 \\
Cyperus rotundus & Poaceae & 5.4 & 4.57 \\
Digitaria sanguinalis & Poaceae & 10.5 & 8.89 \\
Dactyloactenium aegyptium & Poaceae & 2.0 & 1.69 \\
Cenchrus biflorus & Poaceae & 1.2 & 1.02 \\
Cynodon dactylon & Sub total & 23.0 & 24.98 \\
& & & 18.04 \\
B. Dicot weeds & Amaranthaceae & 39.5 & 17.27 \\
Amaranthus viridis & Aizoaceae & 31.3 & 9.48 \\
Trianthema portulacastrum & Amaranthaceae & 20.4 & 4.23 \\
Digera arvensis & Euphorbiaceae & 17.2 & 2.71 \\
Phyllanthus niruri & Euphorbiaceae & 5.0 & 3.81 \\
Euphorbia hirta & Amaranthaceae & 3.2 & 100.0 \\
Celosia argentia & Commelinaceae & 4.5 & \\
Commelina benghalensis & Sub total & 95.1 & 118.1 \\
& Total & &
\end{tabular}


the efficacy of the pendimethalin (Aktar et al., 2008). Sireesha et al. (2011) reported that performance of pendimethalin depends upon the moister in the soil.

\section{Weed control efficiency}

Weed control efficiency was found maximum and significantly higher in imazethapyr @ $0.1 \mathrm{~kg} / \mathrm{ha}$ at 20 days + hand weeding at 40 DAS $\left(\mathrm{T}_{6}\right)$ (96.3 and 97.6 per cent) but it was statistically at par with pendimethalin @ 1 litre/ha + hand weeding at 40 DAS ( $\left.\mathrm{T}_{7}\right)$ (95.4 and 97.0 per cent) and pendimethalin @ 1 litre/ha $(P E)+$ imazethapyr @ $0.1 \mathrm{Kg} / \mathrm{ha}$ at 20 days $(\mathrm{PoE})\left(\mathrm{T}_{8}\right)$ (93.9 and 96.1 per cent) at 30 and 60 DAS, respectively (Table 2). Poor performance of pendimethalin in controlling weeds was due to lack of optimum moisture of the soil which reduced the efficacy of the pendimethalin under rainfed conditions. Sireesha et al. (2011) reported that performance of pendimethalin depends upon the moister in the soil. Goswami et al. (2015) found good control of weed with the application of pendimethalin and imazethapyr in green gram.

\section{Effect on crop}

\section{Growth attributes of clusterbean}

\section{Plant height}

One hand weeding at 20 DAS recorded the highest plant height which was statistically similar with two hand weedings at 20 and 40 DAS, pendimethalin @ 1 litre/ha (PE) + imazethapyr @ $0.1 \mathrm{Kg} / \mathrm{ha}$ at 20 days (PoE) and weedy check, but it was significantly higher than all other treatments at maturity (Table 3). The lowest plant height was achieved with pendimethalin @ 1 litre/ha (PE). It was observed that weeds controlled with different weed managements showed better growth or height due to less competition thus crop enjoyed better water nutrient uptake.

\section{Dry matter}

The data in Table 3 regarding dry matter indicated that the highest dry matter accumulation was attained in imazethapyr @ $0.1 \mathrm{~kg} / \mathrm{ha}$ at 20 days (PoE) + one hand weedings at 40 DAS and it was statistically at par with with the treatments of

Table 2: Effect of weed control measures on weed density and weed control efficiency in clusterbean (pooled data of 2 years).

\begin{tabular}{|c|c|c|c|c|}
\hline \multirow{2}{*}{ Treatment } & \multicolumn{2}{|c|}{ Weed density (per $\mathrm{m}^{2}$ ) } & \multicolumn{2}{|c|}{ Weed control efficiency (\%) } \\
\hline & 30 DAS & 60 DAS & 30 DAS & 60 DAS \\
\hline $\mathrm{T}_{1}:$ Pendimethalin @ 1 litre/ha (PE) & $3.19(10.2)$ & $6.39(40.9)$ & 72.2 & 69.3 \\
\hline $\mathrm{T}_{2}:$ Imazethapyr @ $0.1 \mathrm{~kg} / \mathrm{ha}$ at 20 days (PoE) & $6.07(36.9)$ & $3.03(9.2)$ & 83.6 & 92.7 \\
\hline $\mathrm{T}_{3}:$ Stale bed technology & $2.83(8.0)$ & $3.50(12.3)$ & 79.9 & 85.3 \\
\hline $\mathrm{T}_{4}:$ One hand weeding at $20 \mathrm{DAS}$ & $3.10(9.6)$ & $6.21(38.6)$ & 91.5 & 87.1 \\
\hline $\mathrm{T}_{5}$ : Two hand weedings at 20 and 40 DAS & $3.03(9.5)$ & $2.13(5.1)$ & 91.3 & 95.3 \\
\hline $\mathrm{T}_{6}: \mathrm{T}_{2}+$ hand weeding at $40 \mathrm{DAS}$ & $3.63(13.3)$ & $2.00(4.0)$ & 96.3 & 97.6 \\
\hline $\mathrm{T}_{7}: \mathrm{T}_{1}+$ hand weeding at $40 \mathrm{DAS}$ & $6.27(39.3)$ & $3.13(9.8)$ & 95.4 & 97.0 \\
\hline $\mathrm{T}_{8}: \mathrm{T}_{1}+\mathrm{T}_{2}(\mathrm{PE}+\mathrm{PoE})$ & $2.99(9.0)$ & $2.68(7.2)$ & 93.9 & 96.1 \\
\hline $\mathrm{T}_{9}:$ Weedy check & $9.88(97.7)$ & $9.50(90.4)$ & 0.0 & 0.0 \\
\hline SEm \pm & 0.45 & 0.70 & 1.1 & 0.5 \\
\hline LSD $(P=0.05)$ & 1.55 & 2.90 & 3.1 & 1.8 \\
\hline
\end{tabular}

${ }^{*}$ Data transformed using square root and original values are in parentheses, PE-Pre-emergence, DAS-Day after sowing

Table 3: Effect of weed control measures on growth parameters of clusterbean (pooled data of 2 years).

\begin{tabular}{|c|c|c|c|c|}
\hline \multirow{2}{*}{ Treatment } & \multirow{2}{*}{$\begin{array}{l}\text { Plant height } \\
\text { (cm) }\end{array}$} & \multirow{2}{*}{$\begin{array}{c}\text { Dry matter } \\
\text { accumulation/m } \\
\text { row length }(\mathrm{g})\end{array}$} & \multicolumn{2}{|c|}{ Number of branches/plant } \\
\hline & & & 60 DAS & At maturity \\
\hline $\mathrm{T}_{1}:$ Pendimethalin @ 1 litre/ha (PE) & 84.7 & 105.7 & 3.65 & 8.90 \\
\hline $\mathrm{T}_{2}:$ Imazethapyr @ $0.1 \mathrm{~kg} / \mathrm{ha}$ at 20 days (PoE) & 85.6 & 117.5 & 5.00 & 10.25 \\
\hline $\mathrm{T}_{3}:$ Stale bed technology & 88.4 & 125.0 & 6.05 & 11.30 \\
\hline $\mathrm{T}_{4}:$ One hand weeding at $20 \mathrm{DAS}$ & 100.3 & 112.9 & 3.85 & 9.10 \\
\hline $\mathrm{T}_{5}$ : Two hand weedings at 20 and 40 DAS & 96.4 & 136.9 & 6.65 & 11.90 \\
\hline $\mathrm{T}_{6}: \mathrm{T}_{2}+$ hand weeding at $40 \mathrm{DAS}$ & 92.0 & 155.3 & 9.55 & 14.80 \\
\hline $\mathrm{T}_{7}: \mathrm{T}_{1}+$ hand weeding at $40 \mathrm{DAS}$ & 90.6 & 140.7 & 8.25 & 13.50 \\
\hline $\mathrm{T}_{8}: \mathrm{T}_{1}+\mathrm{T}_{2}(\mathrm{PE}+\mathrm{PoE})$ & 97.7 & 145.0 & 8.65 & 13.90 \\
\hline $\mathrm{T}_{9}:$ Weedy check & 97.2 & 95.2 & 2.90 & 8.15 \\
\hline $\mathrm{SEm} \pm$ & 1.2 & 7.9 & 0.4 & 0.5 \\
\hline LSD $(P=0.05)$ & 5.0 & 26.8 & 1.10 & 1.45 \\
\hline
\end{tabular}


pendimethalin @ 1 I itre/ha (PE) + one hand weedings at 40 DAS, two hand weedings at 20 and 40 DAS and pendimethalin @ 1 litre/ha (PE) + imazethapyr @ 0.1 kg/ha at 20 days (PoE) but was significantly higher than all other treatments. The higher dry matter accumulation with application of pre- and post-emergence herbicide along with hand weeding might be due to increase in growth attributes that was associated with greater resource uptake and photo assimilate production.

\section{Number of branches per plant}

The highest number of branches per plant was attained in imazethapyr @ 0.1 kg/ha at 20 days (PoE) + one hand weedings at 40 DAS and it was statistically at par with pendimethalin @ 1 litre/ha (PE) + one hand weedings at 40 DAS and pendimethalin @ 1 litre/ha (PE) + imazethapyr @ $0.1 \mathrm{~kg} / \mathrm{ha}$ at 20 days (PoE) but was significantly higher than all other treatments (Table 3). The lowest number of branches per plant was achieved with weedy check plots. It was observed that weeds controlled with different weed managements showed higher number of branches per plant due to less competition thus crop enjoyed better water nutrient uptake. It also might be due to application of pre emergence herbicide or post emergence herbicide and hand weeding which minimized weed competition for growth resources and allowed plants to take up enough moisture and nutrients for better growth, thus produced higher number branches plant ${ }^{-1}$.

\section{Yield attributes of clusterbean}

\section{Number of pods/plant}

The maximum number of pods/plant was obtained when imazethapyr @ 0.1 kg/ha was applied at 20 days (PoE) + one hand weeding at 40 DAS which was statistically at par with pendimethalin @ 1 litre/ha (PE) + one hand weeding at 40 DAS and pendimethalin @ 1 litre/ha (PE) + Imazethapyr @ $0.1 \mathrm{~kg} / \mathrm{ha}$ at 20 days (PoE), but it was significantly higher than other treatments (Table 4). The higher number of pods/ plant with application of post-emergence herbicide with one hand weeding at 40 DAS might be due to increase in growth attributes viz., plant height and dry matter led to greater resource uptake and photo assimilate production finally translocated to the reproductive organ.

\section{Number of seeds/pod}

The maximum number of seeds/pod in clusterbean was recorded under imazethapyr @ $0.1 \mathrm{~kg} / \mathrm{ha}$ at 20 days (PoE) + one hand weedings at 40 DAS, which was statistically at par with pendimethalin @ 1 litre/ha (PE) + one hand weedings at 40 DAS and pendimethalin @ 1 litre/ha (PE) + imazethapyr $@ 0.1 \mathrm{~kg} / \mathrm{ha}$ at 20 days (PoE) and it was significantly higher than other treatments (Table 4). The highest number of seeds/

Table 4: Effect of weed control measures on yield attributes of clusterbean (pooled data of 2 years).

\begin{tabular}{lccc}
\hline Treatment & Number of pods/plant & Number of seeds/pod & Seed index $(\mathrm{g})$ \\
\hline $\mathrm{T}_{1}:$ Pendimethalin @ 1 litre/ha (PE) & 14.6 & 4.5 & 2.39 \\
$\mathrm{~T}_{2}:$ Imazethapyr @ 0.1 kg/ha at 20 days (PoE) & 15.9 & 4.9 & 2.39 \\
$\mathrm{~T}_{3}:$ Stale bed technology & 16.5 & 5.4 & 2.38 \\
$\mathrm{~T}_{4}:$ One hand weeding at 20 DAS & 15.2 & 4.7 & 2.40 \\
$\mathrm{~T}_{5}:$ Two hand weedings at 20 and 40 DAS & 17.1 & 5.8 & 2.42 \\
$\mathrm{~T}_{6}: \mathrm{T}_{2}+$ hand weeding at 40 DAS & 21.7 & 6.5 & 2.46 \\
$\mathrm{~T}_{7}: \mathrm{T}_{1}+$ hand weeding at 40 DAS & 19.8 & 6.0 & 2.45 \\
$\mathrm{~T}_{8}: \mathrm{T}_{1}+\mathrm{T}_{2}(\mathrm{PE}+\mathrm{PoE})$ & 20.5 & 6.1 & \\
$\mathrm{~T}_{9}:$ Weedy check & 10.5 & 4.2 & 2.42 \\
$\mathrm{SEm} \pm$ & 0.9 & 0.2 & 2.36 \\
LSD $(\mathrm{P}=0.05)$ & 2.5 & 0.5 & 0.01 \\
\hline
\end{tabular}

Table 5: Effect of weed control measures on productivity and economics of clusterbean (pooled data of 2 years).

\begin{tabular}{|c|c|c|c|c|}
\hline Treatment & Seed yield (kg/ha) & Stover yield $(\mathrm{kg} / \mathrm{ha})$ & Net returns $\left(\times 10^{3} ₹ / \mathrm{ha}\right)$ & $\mathrm{B}: \mathrm{C}$ ratio \\
\hline $\mathrm{T}_{1}:$ Pendimethalin @ 1 litre/ha (PE) & 738 & 2228 & 22.7 & 2.15 \\
\hline $\mathrm{T}_{2}:$ Imazethapyr @ $0.1 \mathrm{Kg} / \mathrm{ha}$ at 20 days (PoE) & 825 & 2443 & 26.8 & 2.41 \\
\hline $\mathrm{T}_{3}:$ Stale bed technology & 875 & 2542 & 27.2 & 2.57 \\
\hline $\mathrm{T}_{4}$ : One hand weeding at $20 \mathrm{DAS}$ & 788 & 2353 & 26.8 & 2.25 \\
\hline $\mathrm{T}_{5}:$ Two hand weedings at 20 and 40 DAS & 900 & 2545 & 27.9 & 2.70 \\
\hline $\mathrm{T}_{6}: \mathrm{T}_{2}+$ hand weeding at $40 \mathrm{DAS}$ & 1055 & 2670 & 32.5 & 3.39 \\
\hline $\mathrm{T}_{7}: \mathrm{T}_{1}+$ hand weeding at $40 \mathrm{DAS}$ & 975 & 2640 & 31.6 & 3.20 \\
\hline $\mathrm{T}_{8}: \mathrm{T}_{1}+\mathrm{T}_{2}(\mathrm{PE}+\mathrm{PoE})$ & 980 & 2692 & 30.8 & 3.11 \\
\hline $\mathrm{T}_{9}:$ Weedy check & 475 & 1717 & 15.8 & 1.67 \\
\hline SEm \pm & 39 & 62 & - & - \\
\hline LSD $(P=0.05)$ & 115 & 210 & - & - \\
\hline
\end{tabular}


pods with imazethapyr @ $0.1 \mathrm{~kg} / \mathrm{ha}$ at 20 days $(\mathrm{PoE})+$ one hand weedings at 40 DAS might be due to increase in growth attributes viz., plant height and dry matter led to greater resource uptake and photo assimilate production finally translocated to the reproductive organ.

\section{Seed index}

The highest seed index of clusterbean was achieved in imazethapyr @ $0.1 \mathrm{~kg} / \mathrm{ha}$ at 20 days (PoE) + one hand weedings at 40 DAS which was statistically at par with pendimethalin @ 1 litre/ha $(\mathrm{PE})+$ one hand weedings at 40 DAS, two hand weedings at 20 and 40 DAS and pendimethalin @ 1 litre/ha (PE) + imazethapyr @ 0.1 kg/ha at 20 days (PoE) which was significantly higher than all other treatments (Table 4). Lowest seed index was found in weedy check treatment. The higher seed index with application of pre-emergence herbicide or two hand weeding might be due to increase in growth attributes that was associated with greater resource uptake and photo assimilate production finally translocated to the reproductive organ.

\section{Productivity of clusterbean}

\section{Seed yield}

The maximum seed yield of clusterbean was obtained when imazethapyr @ $0.1 \mathrm{~kg} / \mathrm{ha}$ at 20 days (PoE) + one hand weedings at 40 DAS (422 kg/ha), being statistically at par with pendimethalin @ 1 litre/ha (PE) + one hand weedings at 40 DAS (390 kg/ha) and pendimethalin @ 1 litre/ha (PE) + imazethapyr @ 0.1 kg/ha at 20 days (PoE) (392 kg/ha) which was significantly higher than other treatments (Table 5). Imazethapyr @ $0.1 \mathrm{~kg} / \mathrm{ha}$ at 20 days (PoE) + one hand weedings at 40 DAS recorded 27.9 and $33.9 \%$ higher seed yield than imazethapyr @ $0.1 \mathrm{~kg} / \mathrm{ha}$ at 20 days (PoE) and one hand weedings at 40 DAS, respectively. Weedy check treatment resulted in the lowest seed yield $(190 \mathrm{~kg} / \mathrm{ha})$ in clusterbean. Pendimethalin @ 1 litre/ha (PE), One hand weeding at 20 DAS (days after sowing) and imazethapyr @ $0.1 \mathrm{~kg} / \mathrm{ha}$ at 20 days (PoE) produced statistically similar seed yield of clusterbean. This may be due to additive effect of number of pods/plant, number of seeds/pod. Narkhede et al. (2000) observed that two hand weeding and hoeing in sesame significantly gave higher seed yield than rest of the integrated weed management practices.

\section{Stover yield}

Weed control practices significantly improved the stover yield of clusterbean (Table 5). The highest stover yield was recorded in imazethapyr @ $0.1 \mathrm{~kg} / \mathrm{ha}$ at 20 days (PoE) + pendimethalin @ 1 litre/ha (PE), which was statistically at par with pendimethalin @ 1 litre/ha (PE) + one hand weedings at 40 DAS and imazethapyr @ $0.1 \mathrm{~kg} / \mathrm{ha}$ at 20 days (PoE) + one hand weedings at 40 DAS but it was significantly higher than other treatments.

\section{Economics}

The net returns and benefit-cost ratio were maximum for imazethapyr @ 0.1 kg/ha at 20 days (PoE) + hand weeding at 40 DAS $\left(\mathrm{T}_{6}\right)$ (Table 4$)$. It was followed by pendimethalin @ 1 litre/ha $(P E)+$ hand weeding at $40 \mathrm{DAS}\left(\mathrm{T}_{7}\right)$ with $\mathrm{B}: \mathrm{C}$ ratio of 3.20 and pendimethalin @ 1 litre/ha $(P E)+$ imazethapyr @ $0.1 \mathrm{~kg} / \mathrm{ha}$ at 20 days (PoE) $\left(\mathrm{T}_{8}\right)$ with $\mathrm{B}: \mathrm{C}$ ratio of 3.11 .

\section{CONCLUSION}

Generally, farmers sow clusterbean on rainfed conditions but seldom adopt weed control practices in it. It becomes very difficult and uneconomical to maintain weed free environment throughout crop period in rainfed conditions. Keeping the field weed free with 2-3 hand weedings is laborious, time consuming and costlier weed management practice. In clusterbean which is a rainfed crop and application of pendimethalin or imazethapyr alone is not found effective to control weeds under such conditions. Imazethapyr @ $0.1 \mathrm{~kg} / \mathrm{ha}$ at 20 days (PoE) + one hand weedings at 40 DAS recorded 27.9 and $33.9 \%$ higher seed yield than imazethapyr @ $0.1 \mathrm{~kg} / \mathrm{ha}$ at 20 days (PoE) and one hand weedings at 40 DAS, respectively. The net returns and benefit: cost ratio were higher under imazethapyr @ $0.1 \mathrm{~kg} / \mathrm{ha}$ at 20 days (PoE) + hand weeding at $40 \mathrm{DAS}\left(\mathrm{T}_{6}\right)$. Therefore, imazethapyr @ 0.1 kg/ha at 20 days (PoE) + one hand weedings at 40 DAS was found the most effective and economic approach for weed control in clusterbean under rainfed conditions.

\section{REFERENCES}

Aktar, M.W., Sengupta, D, Purkait, S. and Chowdhury, A. (2008). Vertical migration of some herbicides through undisturbed and homogenized soil columns. Interdisciplinary Toxicology. 1 (3-4): 231-235.

Anonymous, (2021). Ministry of Agriculture, Govt. of India. www.indiastat.com.

Goswami, G., Kumar, S., Bhushan, C. and Shukla, A. (2015). Effect of weed management practices under various fertility levels on weed index and weed control efficiency of spring mungbean. Environment and Ecology, 33: 402-404.

Grichar, W.J., Sestak, D.C., Brewer, K.D., Besler, B.A., Stichler, C.R. and Smith, D.T. (2001). Sesame (Sesamum indicum L.) tolerance and weed control with soil applied herbicides. Crop Protection. 20: 389-394.

Gupta, V., Singh, M., Kumar, A., Sharma, V.C. and Kher, D. (2014). Effect of different weed management practices in urdbean [Vigna mungo (L.) Hepper] under sub-tropical rainfed conditions of Jammu (India). Legume Research. 37(4): 424-429.

Islam, M.A., Mamun, A.A., Bhuiyan, M.S.U. and Hossain, S.M.A. (1989). Weed biomass and grain yield in wheat as affected by seed rate and duration of weed competition. Bangladesh Journal of Agricultural Science. 14: 213-224.

Knezevic, S.Z., Evans, S.P., Blankenship, E.E., Van Acker, R.C. and Lindquist, J.L. (2002). Critical period for weed control: The concept and data analysis. Weed Science. 50: 773-786.

Langham, D.R., Grichar, W.J. and Dotray, P.A. (2007). Review of herbicide research on sesame (Sesamum indicum L.). Version 1. www.sesamegrowers.org, accessed Aug, 2010. 
Mani, V.S., Malla, M.L., Gautam, K.C. and Bhagwandas (1973) Weed killing chemicals in potato cultivation. Indian Farming. 72: 17-18.

Meena, V.K., Kaushik, M.K., Singh, M., Kumar, Rakesh., Meena, R.K., Meena, B.L., Ram, B.P.H., Kumar, U., Yadav, M.R., Makarana, G., Kumar, Sourabh. and Joshi, Deepa. (2016). Performance of cluster bean cultivars under the application of various agrochemicals in Sub - Humid area of Rajasthan, India. Legume Research. 39: 982-986.

Mishra, R. (1968). Community Structure Ecology Workbook. Oxford IBH Publ. Co. New Delhi. pp. 31-34.
Narkhede, T.N., Wadile, S.C., Attarde, D.R. and Suryawanshi, R.T. (2000). Integrated weed management in sesame under rainfed conditions. Indian Journal of Agricultural Research. 34(4): $247-250$.

SAS. (2017). Version 9.4. Inc Cary (NC, USA.): SAS Institute. Sireesha, A., Rao, P.C., Swapna, G. and Ramalakshmi, S. (2011). Persistence of pendimethalin and oxyyflourfen at different temperature and moisture levels in an alfisol and vertisol. Indian Journal of Weed Science. 43: 181-187.

Verma, L. and Kushwaha, H.S. (2020). Evaluation of different herbicides against weeds in mungbean (Vigna radiata L.). Legume Research. 43(6): 866-871. 